
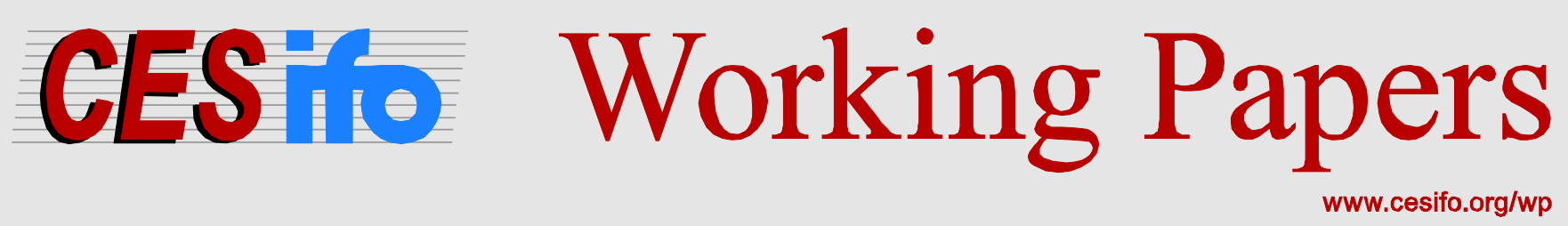

\title{
Diversification, Dutch Disease, and Economic Growth: Options for Uganda
}

\author{
Thorvaldur Gylfason \\ Jean-Pascal Nguessa Nganou
}

\author{
CESIFO WORKING PAPER NO. 5095 \\ CAtegory 6: Fiscal Policy, Macroeconomics and Growth \\ NOVEMBER 2014
}
An electronic version of the paper may be downloaded
- from the SSRN website:
- from the RePEc website:
- from the CESifo website:
WwW.SSRN.com
www.RePEc.org
www.CESifo-group.org/wp

\section{CESifo}




\title{
Diversification, Dutch Disease, and Economic Growth: Options for Uganda
}

\begin{abstract}
Natural resource discoveries, even when fairly modest in terms of the revenues they are expected to generate, can have significant macroeconomic effects and implications for the conduct of fiscal and monetary policy. In this respect, Uganda is no different from other oilrich countries. In five main ways, all of which suggest the need for economic diversification as an efficient risk management strategy, the Dutch disease manifests itself through (i) An appreciation of the local currency in real terms, undermining the profitability of other export industries, and of local industries competing with imports by encouraging imports. (ii) The increased volatility of the real exchange rate induced by oscillating oil prices in world markets, which reduces investment and economic growth over time. (iii) Wage increases in the resource-intensive sector that spill over to the non-resource-based sector, further hampering employment and investment in the non-resource-based sector. (iv) Socially counterproductive rent seeking (and even plundering) in the absence of effective legal and institutional mechanisms that would ensure resource rents accrue to the rightful owners with minimal leakages, and are managed for the benefit of all. (v) Crowding out, by which natural capital (if not well managed) tends to undermine other types of capital essential to economic development, including human and social capital. The need for diversification can be viewed in terms of channeling the revenues generated by resource rents into the generation of human capital through education and training, and social capital through institution building conducive to good governance and transparency, aiming, inter alia, to keep rent seeking at bay. Economic diversification for the purpose of containing the preponderance of the resource-intensive industry at the expense of other industries, and political diversification through democracy aimed at encouraging pluralism and high-quality leadership both convey parallel principal benefits to the economy and society in terms of efficiency and fairness.
\end{abstract}

JEL-Code: F430, O130, O430.

Keywords: Dutch disease, export diversification, economic growth, Uganda.

\author{
Thorvaldur Gylfason \\ University of Iceland \\ gylfason@hi.is
}

\author{
Jean-Pascal Nguessa Nganou \\ World Bank \\ jnganou@worldbank.org
}




\section{Introduction}

Now that Uganda has discovered significant amounts of oil within its territory, there is a need for the people of Uganda and their government to assess the experiences of other countries that have made similar natural resource discoveries in the past. Some of those countries have disappointingly little to show for their resource riches while others - Botswana and Mauritius, for example - have fared quite well. Experience shows that natural resources can prove to be a mixed blessing, a point succinctly summarized by Spence et al. (2008, 8-9):

"Economies blessed with abundant oil, minerals, or other natural resources should be able to invest the "rents" or proceeds at home, raising their growth potential. But the historical experience has most often been the reverse. The pitfalls are well known. Sometimes the state sells extraction rights too cheaply or taxes resource revenues too lightly. Sometimes the money it raises is stolen or squandered by rent-seeking elites and vested interests. When the money is invested, it is not always invested wisely or transparently. And by providing a ready source of foreign-exchange, natural resources can also reduce incentives for diversifying exports, a predicament known as "Dutch disease." States will improve on this sorry historical record only if they capture an appropriate share of the resource rents; save a judicious amount overseas; and set clear, growth-oriented priorities for absorbing the remainder at home."”

Abundant natural resources may attract the wrong sort of people to politics - politicians who team up with rent-seekers focused on the transfer of wealth rather than creation of wealth. Such politicians often impart a false sense of security, a feeling that abundant natural resource wealth somehow makes it unnecessary to accumulate human capital and social capital to lay a lasting foundation for inclusive economic growth.

According to current estimates, Uganda's oil reserves are neither enormous nor trivial. They will not catapult Uganda to quick success nor do they seem likely, on their own, to stir serious macroeconomic trouble should things go awry. According to Henstridge and Page (2012), the oil discoveries announced in 2006 are expected to generate rather modest revenues equivalent to between three percent and nine percent of GDP each year, over a period of 20 years (ending in 2030 or thereabouts). ${ }^{4}$ According to recent Government sources, total oil reserves of Uganda are believed to be around 3.5 billion barrels, with recoverable reserves estimated at 0.8-1.2 billion barrels. Based on this picture, government revenue from oil could account for about 10-15 percent of GDP (assuming a peak daily production of 120,000-210,000 barrels) over a production period of 20-30 years. Recent economic growth literature suggests several

\footnotetext{
${ }^{3}$ This is an old story. As Tignor (2006, Ch. 5) reports, W. Arthur Lewis resigned in 1958 as Ghana's Chief Economic Adviser on account of his displeasure with, among other things, President Nkrumah's insistence on selling Ghana's energy to foreign companies at prices that Lewis thought too low.

${ }^{4}$ These estimates also confirm that the new sector could represent about 4 percent of GDP on average for the next 20 years ending in 2037 .
} 
ways of increasing GDP by comparable amounts or more by encouraging saving, investment, social efficiency, and sound institutions. Empirical evidence suggests that realistic increases in domestic saving and investment rates, school enrolment rates, foreign trade and investment, democracy, good governance, and so on, can significantly encourage long-run economic growth (Growth Commission 2008). The revolution of living standards in several Asian countries since the 1960s seems by and large to support these findings. Recent evidence from Africa also points to significant progress, illustrated more clearly by various social indicators (decreasing child mortality and fertility, for example) than by standard economic indicators such as per capita GDP (Young, 2012). This suggests that, ideally, Uganda would need to make an all-out effort on many fronts at once, including strong, industry-standard emphasis on judicious management of its newfound oil wealth within an appropriate institutional setup.

Table 1: Oil Production in selected countries

\begin{tabular}{|c|c|c|c|c|c|c|c|}
\hline Country & $\begin{array}{c}\text { Population } \\
\text { (mil) }\end{array}$ & $\begin{array}{c}\text { Oil } \\
\text { Reserves } \\
(\text { mil bbl) }\end{array}$ & $\begin{array}{c}\text { Oil } \\
\text { Reserves } \\
\text { per } \\
\text { capita } \\
\text { (bbl) }\end{array}$ & $\begin{array}{c}\text { Oil } \\
\text { Production } \\
(\text { mil bbl) }\end{array}$ & $\begin{array}{c}\text { Oil } \\
\text { Prod } \\
\text { per } \\
\text { capita } \\
\text { (bbl) }\end{array}$ & $\begin{array}{c}\text { Refined } \\
\text { Petrol } \\
\text { Production } \\
\text { (mil bbl) }\end{array}$ & $\begin{array}{c}\text { Refined Petrol } \\
\text { Consumption } \\
\text { (mil bbl) }\end{array}$ \\
\hline Algeria & 38.5 & 12,200 & 317 & 1.88 & 0.05 & 0.57 & 0.32 \\
\hline Angola & 20.8 & 10,470 & 503 & 1.87 & 0.09 & 0.04 & 0.08 \\
\hline Chad & 12.4 & 1,500 & 120 & 0.10 & 0.01 & 0.00 & 0.00 \\
\hline Congo & 50.0 & 1,600 & 32 & 0.29 & 0.01 & 0.01 & 0.01 \\
\hline Egypt & 80.7 & 4,400 & 55 & 0.72 & 0.01 & 0.60 & 0.82 \\
\hline Eq. Guinea & 0.7 & 1,100 & 1,494 & 0.32 & 0.43 & 0.00 & 0.00 \\
\hline Gabon & 1.6 & 2,000 & 1,225 & 0.24 & 0.15 & 0.02 & 0.02 \\
\hline Libya & 6.2 & 48,010 & 7,801 & 1.48 & 0.24 & 0.39 & 0.31 \\
\hline Nigeria & 168.8 & 37,200 & 220 & 2.52 & 0.01 & 0.10 & 0.27 \\
\hline Qatar & 2.0 & 25,380 & 12,377 & 1.58 & 0.77 & 0.29 & 0.17 \\
\hline South Sudan & 10.8 & 3,750 & 346 & 0.09 & 0.01 & & \\
\hline Sudan & 37.2 & 1,250 & 34 & 0.03 & 0.00 & 0.12 & 0.10 \\
\hline Uganda & 36.4 & 2,500 & 69 & 0.00 & 0.00 & 0.00 & 0.02 \\
\hline
\end{tabular}

Sources: Various, including World Bank, World Development Indicators, and CIA. 
Fig. 1. Uganda: Incomes and Family Size

Per capita GNI (USD, ppp) 1982-2012

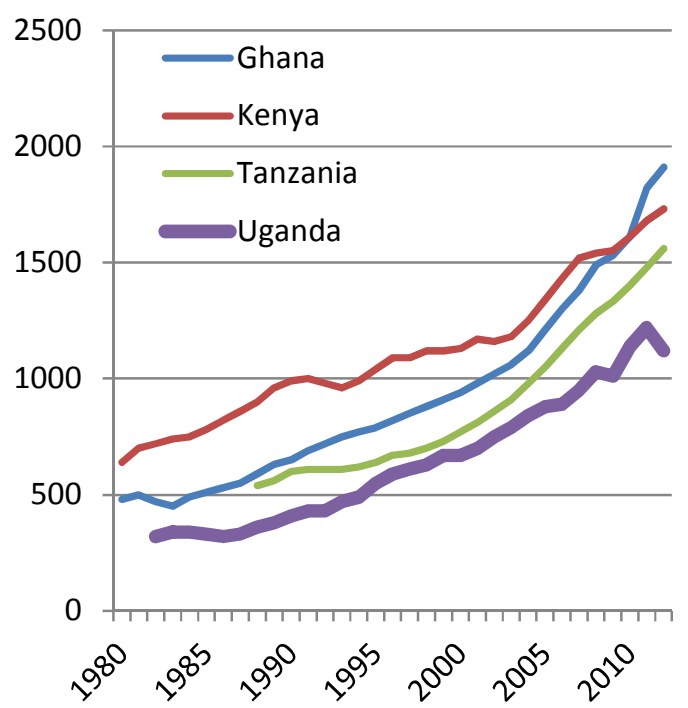

Fertility (births per woman) 1961-2011

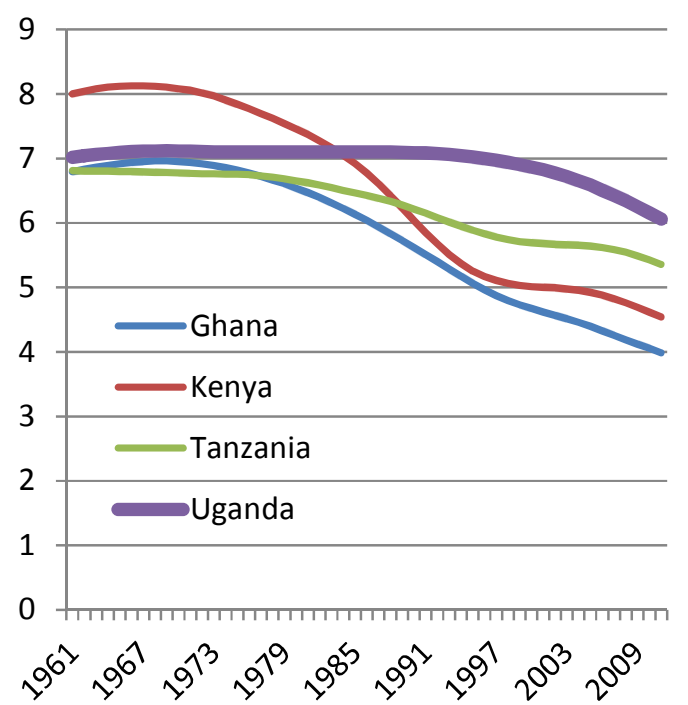

Source: World Bank, World Development Indicators.

Uganda's recent development and its initial position with oil production in its infancy are illustrated in Figure 1. Compared with Kenya, Tanzania, and Ghana, the purchasing power of Uganda's gross national income (GNI) has lagged behind the other three countries over the past 30 years. The slow reduction in fertility in Uganda confirms this impression. Reduced fertility is a strong indicator of economic and social advances and of human capital formation in particular. This is explained by the fact that, in large families, relatively fewer children have full access to the education opportunities that their parents would like them to have if they could afford it. At 58 years in 2012, life expectancy at birth in Uganda remains 2-3 years below that in Kenya, Tanzania, and Ghana, just as in 1961 (except Tanzania and Uganda were then about even at 44 years). These considerations are important because, as Prof. Hans Rosling has pointed out in several of his celebrated lectures, economic progress means, among many other things, moving from short lives in large families to long lives in small families. Reduced fertility is both a cause and a consequence of rising incomes. This explains why social policies, including family planning, have taken center stage on Uganda's growth agenda, in addition to economic policies aiming to promote saving and investment, as well as increased efficiency through more and better education, infrastructure, foreign trade, and institutional reforms (Gylfason, 2012). With many remaining opportunities to be exploited in full, Uganda faces bright prospects for economic growth. How can Uganda assess and emulate the experience of those countries that successfully managed their oil discoveries? How can Uganda avoid the mistakes made by those that did less well? This paper addresses these questions selectively by 
emphasizing (a) economic and political diversification away from excessive dependence on oil and other natural resources; (b) aspects of the Dutch disease and how to stay clear of it; and (c) popular rights to common-property natural resources from a legal, human-rights point of view.

\section{Diversification and the Dutch Disease}

Concerning diversification, including the need to transform oil wealth into other types of growth-friendly wealth including human resources and social capital, it needs to be stated up front that there exists no universally acknowledged blueprint for such a transformation. Even so, a number of poignant ideas about economic diversification have emerged from academic literature, as well as policy debates. These ideas are derived from economic analysis, and from the experience of several countries around the world that have managed to successfully diversify their economies and to support sustainable and equitable management of the extractive sector for human development. These economies have also emphasized the need for transparency in the management and disbursal of natural resource rents (see, e.g., Gelb, 2011, and Hausmann et al., 2014).

Mauritius is a case in point. Frankel (2012) shows how Mauritius managed to reduce its reliance on its main export commodity (sugar), mainly by expanding foreign trade as well as education. The share of manufactures in merchandise exports increased from a minuscule amount in 1970 to about 60 percent in recent years, compared with 35 percent in Uganda and Kenya, and 25 percent in Tanzania. Exports of goods and services from Mauritius are at present equivalent to more than a half of its GDP, compared with 25 percent to 30 percent in Uganda, Kenya, and Tanzania. Mauritius has kept inflation under control, which is a sign of essentially sound fiscal and monetary policies. From 1981 to 2012, inflation in Mauritius was seven percent per year on average compared with 38 percent in Uganda, thirteen percent in Kenya, and nineteen percent in Tanzania (World Bank, World Development Indicators). These efforts have paid off. Since 1980, the economy of Mauritius has grown in tandem with that of Botswana, Africa's richest country in terms of the purchasing power of its per capita GNI. Those comparisons and experiences are relevant to Uganda.

Transparency is fundamental to natural resource management, and is fostered by openness - 'glasnost,' for example. This could be achieved through the involvement of international expert groups - e.g., independent NGOs such as Revenue Watch or other trusted advisors - asked to guide the government on methods of resource management and ways to stave off rent seeking and corruption that otherwise, without appropriate checks and balances, might be difficult to avert. In this context, capacity development and institution building are key, including legal safeguards for a free press and an independent judiciary. Full and unfettered transparency can be to natural resource management what effective financial supervision can be to the banking sector. In other words, it is an essential complement, without which 
natural resource rents may be dissipated without benefitting the state or the people, the rightful owners of the resources by international law. This problem is not a new one, as Bastiat (1848) reminds us: "When plunder becomes a way of life for a group of men living in society, they create for themselves, in the course of time, a legal system that authorizes it and a moral code that glorifies it."

The 'old economic geography,' emphasizing the economic and strategic importance of abundant natural resources, now shares the stage with the 'new economic geography' that acknowledges the fact that many countries have managed to prosper without any natural resource possessions (land-locked Switzerland is a case in point, as is Austria), while other countries have languished for long periods despite significant, sometimes even huge, natural resource endowments and discoveries. This observation - once expressed succinctly by President Vladimir Putin of Russia as: "Our country is rich, but our people are poor" - gave rise to the literature on the 'resource curse' by which is meant the possibility that natural resource wealth, if not well managed, may prove to be a mixed blessing (Sachs and Warner, 1995). The resource curse works through various mechanisms, including the Dutch disease in its different guises, including: an overvaluation of the currencies of resource-rich countries, and the volatility of exchange rates, export revenues, and output in addition to other channels of transmission to be discussed below.

The exchange rate channel of the Dutch disease is clear. A boost to foreign exchange earnings following a natural resource discovery increases the supply of foreign exchange in the domestic market, thus driving down the price of foreign exchange and making the local currency appreciate in real terms. This means that total exports - that is, resource plus non-resource exports - will rise mainly as a result of the increase in resource exports. Meanwhile, non-resource exports will fall, as they cannot compete as easily in foreign markets when the currency rises in value, as a higher value of the currency translates into fewer local currency units (e.g., Uganda Shillings) earned from each foreign currency units (e.g., dollar or euro) of export earnings. Therefore, rising currency values in natural resource-rich countries may undermine the exports of manufactures and services, weakening the long-run economic growth potential of the resourcerich country even as a boost to total export earnings can fuel economic activity in the short run. There is no inconsistency involved here. Just as increased consumption at the expense of national saving tends to increase output in the short run and reduce its rate of growth in the long run, a natural resource discovery or, for that matter, a commodity price boom can boost economic activity in the short run while undermining efficiency and economic growth potential over the long haul.

If it takes hold, the Dutch disease may impact Uganda through both the agriculture and tourism sectors. Like elsewhere, agriculture in Uganda is bound to contract over time in terms of both manpower use and its share of GDP as modern farming methods necessitate fewer and fewer working hands to feed the population, a process that would be quickened by a rising real exchange rate reducing the profitability of farm exports. Tourism, on the other hand, faces no natural constraints apart from environmental 
considerations, but may also suffer from reduced profitability due to an appreciation of the shilling in real terms as well as from price hikes for services triggered by expatriate workers in the oil sector. The tourism, oil sector, and emerging industries (Hausmann et al., 2014) need to position themselves to train and absorb unskilled workers leaving the agriculture sector.

In another guise, the Dutch disease often manifests itself through import protection or subsidies which reduce the demand for foreign exchange, thereby lowering the price of foreign currencies and contributing to an appreciation of the local currency, with deleterious consequences for export firms as well as local industries competing with imports. Often, the same political forces favor the protection of selected domestic industries against foreign competition and the indirect subsidization of the naturalresource-based industries by not charging them enough for their extraction rights. In addition, taxing the resource revenues of these domestic industries too lightly could lead to significant overvaluation of the currency and associated balance of payments and external debt problems as a result. This aspect of the Dutch disease brings fiscal policy into the story because it often takes a fiscal correction to create conditions for establishing a competitive value of the local currency.

The advent of oil will confront Uganda with an even greater need than before to exercise fiscal and monetary restraint for the purpose of keeping inflation in check, while at the same time countering the tendency toward overvaluation of the shilling. This can be quite a challenge because an appreciation of the currency in real terms reduces inflation in the short term, creating a policy bias in favor of appreciation as an auxiliary instrument in the fight against inflation. Therefore, keeping inflation under control by other means, i.e., with fiscal and monetary restraint, without resorting to real appreciation of the shilling, becomes even more important than before. This is a relevant consideration in view of the fact that the Ugandan shilling has depreciated in nominal terms by eighteen percent per year on average since 1986 compared with six percent in Kenya and fourteen percent in neighboring Tanzania.

Volatility is a separate issue. Volatility of commodity prices produces fluctuations in exchange rates, export earnings, output, and employment, thereby discouraging investment and growth (Aghion and Banerjee, 2005). For this reason as well, natural-resource rich countries may be prone to sluggish investment and slow growth due to export price volatility. In like manner, high and volatile exchange rates tend to slow down investment and growth.

Since 1960, oil exporting countries have withstood sharp price volatility, which can be attributed to several exogenous factors including political events in oil-producing countries, hurricanes in the Gulf of Mexico, and increasing global demand for petroleum products. Matovu and Nganou (2014) present a brief survey of empirical studies discussing how pro-cyclical are fiscal policies in OPEC states. Budget financing constraints are often mentioned among the main factors underlying pro-cyclical fiscal policies. Frankel (2011) argues that an inflation targeting monetary policy that emphasizes export commodities 
(Product Price Targeting) could render countercyclical fiscal policies more effective. As proposed by Frankel (2011), countries should adopt fiscal policies that emulate the Chilean example. Chile has been successful in avoiding over-spending in boom times while only allowing deviations from a target surplus in response to permanent commodities price changes (Matovu and Nganou, 2014).

\section{From Natural Capital to Diverse Kinds of Capital}

Several further channels through which natural resource wealth may prove to be a mixed blessing independently of exchange rates have been identified in recent growth literature. These channels can be placed under the heading of human, physical, social, and financial capital.

\section{Human capital}

Countries rich in natural resources may lose sight of the need to build up human capital through education and training. There is some evidence that resource-rich countries tend to allocate a smaller share of their national income to education and to send fewer children and adolescents to school than do countries with fewer natural resources, but at the same general income level (Gylfason, 2001, 2012). One possible explanation for this observed pattern is that in resource-rich countries a false sense of economic security may set in, making the authorities and perhaps also some segments of the population lose sight of the need to build up human capital. This phenomenon is well known in human affairs. Wealthy parents sometimes have difficulty convincing their children to acquire an education or even to work. Why work if you can play?

\section{Physical capital}

If this is so, the argument can be extended to other kinds of investment, for example, in physical capital. The quality of physical capital is hard to gauge, however. National income accounts do not yet distinguish between productive and unproductive investment expenditures because investment, like other expenditure, is measured by input rather than by output. The point is simple: partly due to myopia, natural resources rich countries may be less careful about the quality of the investments they make in real capital than are countries with few resources, because resource-poor countries can ill afford to make mistakes. Many resource-rich countries are littered with white elephants. Clearly, improving the efficiency of public investment management (PIM) in terms of appraisal, selection, implementation, and evaluation of projects could enlarge the fiscal space for developing countries to invest in infrastructure much needed for their growth and development. However, the 2011 Public Investment Management Index (PIMI) of World Bank and IMF, which ranks countries in terms of the quality of public investment, is a good step toward addressing quality of physical capital. For a new resource-rich country such as Uganda, the efficiency of public expenditure will be crucial in order to prepare for the advent of resources from oil and other extractives. 


\section{Social capital}

The same argument applies to social capital in its many guises. Here, social capital is the societal infrastructure that keeps economic activity humming along efficiently, including governance, independent judiciaries, freedom of press, trust, equality, and the absence of corruption and political oppression (for a survey, see Paldam, 2000). There is some evidence that just as natural capital, if not judiciously managed, tends to crowd out human and physical capital, it can also crowd out social capital in several dimensions. For example, there is evidence that countries rich in natural resources tend to be awarded lower governance scores according to the Ibrahim index of African governance. Of the twelve African countries that produce oil in commercial quantities, six are among the bottom twenty percent in the Ibrahim ranking of governance that includes Safety and Rule of Law, Participation and Human Rights, Sustainable Economic Opportunity, and Human Development (Ampratwum and Ashon, 2012). Of the 52 African countries ranked by the Ibrahim index in 2013, Uganda ranks number eighteen, compared with 21 for Kenya, seventeen for Tanzania, and seven for Ghana. On a scale from eight (Somalia) to 83 (Mauritius), Uganda scores 56, Kenya 54, Tanzania 57, and Ghana 67. Table 2 provides some further figures on aspects of the oil sector, physical capital, and social capital in thirteen African countries, including Uganda.

Table 2: Oil, Physical Capital, and Social Capital

\begin{tabular}{|c|c|c|c|c|c|c|c|c|c|c|}
\hline Country & $\begin{array}{r}\text { GNI } \\
(\text { Bn } \\
\text { USD) }\end{array}$ & $\begin{array}{c}\text { Gov Oil } \\
\text { Rev (\% } \\
\text { of } \\
\text { GDP) }\end{array}$ & $\begin{array}{c}\text { Headcount } \\
\text { Poverty ratio } \\
(\%)\end{array}$ & $\begin{array}{c}\text { Public } \\
\text { Inv (\% } \\
\text { of GDP) }\end{array}$ & $\begin{array}{c}\text { Private } \\
\text { Inv (\% } \\
\text { GDP) }\end{array}$ & $\begin{array}{c}\text { FDI } \\
(\% \text { of } \\
\text { GDP) }\end{array}$ & Rail & $\begin{array}{c}\% \\
\text { Paved } \\
\text { Roads }\end{array}$ & $\begin{array}{c}\text { Urban } \\
\text { Popu- } \\
\text { lation } \\
\text { growth } \\
(\%)\end{array}$ & $\begin{array}{c}\text { Global } \\
\text { Competi- } \\
\text { tiveness } \\
\text { Index } \\
\text { (Rank out } \\
\text { of 148) }\end{array}$ \\
\hline Algeria & 203.6 & 25.2 & 23.0 & 14.4 & 26.3 & 11.1 & 3,973 & 77.1 & 3.0 & 100 \\
\hline Angola & 102.6 & 34.4 & 40.5 & 9.0 & 6.0 & 14.9 & 2,764 & 10.4 & 4.4 & 142 \\
\hline Chad & 9.8 & 15.6 & 80.0 & 12.5 & 16.3 & 34.9 & 0 & 0.5 & 3.4 & 148 \\
\hline Congo & 10.8 & 2.1 & & 0.0 & 0.0 & 0.0 & 886 & 5.0 & 3.3 & \\
\hline Egypt & 256.4 & 0.0 & 20.0 & 0.0 & 0.0 & 29.4 & 5,083 & 92.0 & 2.0 & 118 \\
\hline Equ. Guinea & 11.0 & 18.5 & & 19.6 & 31.4 & 0.0 & 0 & 0.0 & 3.2 & \\
\hline Gabon & 16.4 & 16.5 & & 13.8 & 17.2 & 0.0 & 649 & 12.0 & 2.8 & 112 \\
\hline Libya & 0.0 & 69.2 & 33.0 & 4.9 & 11.6 & 20.6 & 0 & 57.2 & 1.1 & 108 \\
\hline Nigeria & 241.3 & 21.5 & 70.0 & 6.4 & 16.1 & 28.4 & 3,505 & 15.0 & 4.0 & 120 \\
\hline Qatar & 0.0 & 24.2 & & 14.4 & 14.0 & 16.7 & & & 7.2 & 13 \\
\hline South Sudan & 9.3 & 0.0 & 50.6 & 0.0 & 0.0 & 0.0 & 236 & 0.0 & 5.4 & \\
\hline Sudan & 56.4 & 2.8 & 46.5 & 0.0 & 0.0 & 0.0 & 5,978 & 36.3 & 2.5 & \\
\hline Uganda & 16.8 & 1.4 & 24.5 & 7.6 & 12.7 & $\ldots$ & 1,224 & 16.3 & 6.0 & 129 \\
\hline
\end{tabular}

Sources: Various, including WDI and IMF. 
There is also evidence that countries rich in natural resources tend to be awarded lower corruption perceptions rankings, suggesting more corruption, according to Transparency International. Examples are in abundance. Further, there is evidence that resource-rich countries tend to be less democratic than countries with fewer natural resources, if democracy is measured by the Polity IV index compiled by political scientists at the University of Maryland, for instance (more on this in Section V). Further, there is some empirical evidence to suggest that income inequality as measured by the Gini coefficient, for example, is generally greater in resource-rich countries than in countries with fewer natural resources (Gylfason and Zoega, 2003). Quantitative indicators of trust - e.g., the confidence that people say they have in their countries' institutions such as banks or courts or media - are quite recent and have not yet been included in statistical research on the relationship between natural resources and economic growth, but they are gaining ground.

\section{Financial capital}

Abundant natural resources may also crowd out financial capital by holding back the emergence of a well-developed financial system, and producing an inefficient allocation of savings across industries and firms. This reduces the average efficiency of capital by weakening incentives to save and invest. When a significant part of a country's national wealth takes the form of natural resources, whether renewable or nonrenewable, there is less need for banks and other financial institutions to facilitate everyday transactions. The country can save through less rapid depletion or more rapid renewal with renewable natural resources, or it can spend through more rapid depletion of the natural resource (Arezki and Gylfason, 2011; Gylfason and Zoega, 2006). In the OPEC states, savings are stored as deposits in foreign banks, making domestic financial intermediation even less important. On the other hand, when savings are accumulated at home in the form of physical capital, domestic banks and stock markets make a difference. By connecting domestic savers and investors, the domestic banking system contributes to a more efficient allocation of capital across sectors and firms. In sum, it is possible for an abundance of natural resources to hamper the development of the financial system, thus distorting the allocation of capital and reducing economic growth due to a negative effect of shallow financial markets on the quantity and quality of saving and investment. There is empirical evidence that indicators of financial development are significant sources of economic growth, physical capital accumulation, and improvements in the efficiency of capital allocation (King and Levine, 1993a, 1993b). If so, natural resource dependence may go along with financial backwardness, thereby hindering efficient capital deepening and economic growth.

All in all, natural capital differs from other kinds of capital - human capital, physical capital, social capital, and financial capital - in one key fashion: the other types of capital never give rise to calls for diversification away from them. No country has ever felt economically challenged by its abundance of or 
dependence on its human or social capital. Natural capital is different because experience seems to suggest that it sometimes sets in motion processes - the Dutch disease through overvalued and volatile currencies, rent seeking, plundering, lack of respect for democracy, and neglect of the need for accumulating other kinds of capital and for economic diversity essential for social efficiency and growth - that may undermine long-run economic growth.

\section{Rent Seeking, Subsidies, and Transparency}

A further channel through which plentiful natural resources may hamper economic efficiency and growth is rent seeking (Krueger, 1974). Output produced from natural resources differs from many other commodities in that it costs very little to produce relative to the earnings it generates. For example, an oil shipment that can be sold for a million dollars may have cost only $\$ 200,000$ to produce, leaving a rent of $\$ 800,000$ in the pocket of the producer. This helps explain why, if the property rights of the people to their natural resources are not well protected, natural resource wealth may attract unscrupulous people to politics.

An example may help. Citing a report from Citigroup, the Financial Times reported on 9 July 2011 that the retail value of Russia's natural resources amounted to about $\$ 650$ billion per year while the cost of production amounted to roughly $\$ 150$ billion. If so, Russia's natural resource rent amounts to about $\$ 500$ billion each year, an amount equivalent to around a fifth of Russia's annual GDP measured in terms of purchasing power. Clearly, it matters greatly to whom the rent accrues and how it is divided among the recipients. According to the Citigroup report, more than 60 percent ( $\$ 310$ billion) of Russia's natural resource rent originates in the oil sector, about a third ( $\$ 160$ billion) in the natural gas sector, and the rest in the minerals sector. The report states that 58 percent of the rent accrues to the state through taxes and that another eighteen percent accrues to consumers through subsidies of gasoline, among other things. That makes a total of 76 percent of the rent. A sixth of the rent, or sixteen percent, is devoted to investment, according to the report, and the rest, eight percent, accrues to shareholders, including oligarchs. These figures are cited here only to give a ballpark idea of the amounts and proportions involved; other studies may well arrive at different figures. For comparison, about 80 percent of the oil rent in Norway has accrued to the state over the years through taxes, royalties, etc., with minimal subsidies involved (more on Norway in Section VII).

Many, if not most oil-rich countries choose to subsidize gasoline at a high cost in terms of inefficiency and associated deadweight losses (Aguinaga et al., 2014). Selling fuel at cost price at home rather than at the world market price, even including taxes, is tantamount to a subsidy on fuel. Subsidizing fuel is inherently inefficient because selling domestically produced fuel at home at a lower price than could be fetched in the world market deprives producers of revenues, thereby reducing national income. 
Artificially inexpensive fuel discourages firms and households from conserving energy, inviting waste. Further, the indirect subsidy involved discriminates against those recipients who might have preferred other things had the subsidy been paid out in cash rather than in kind as cheap fuel, as well as against those who do not use much fuel, perhaps because they cannot afford a car. A tax on petrol aimed at bringing its price at the pump closer to world market prices would raise revenue to finance education, health care, and infrastructure. If the tax proceeds are used to bolster the education system, the fuel subsidy is, in effect, replaced by a subsidy to education. Prices at the pump span a wide range, even across oil producing states. In 2012, gasoline at the pump cost sixteen cents per liter in Saudi Arabia, 23 cents in Kuwait, 62 cents in Nigeria, and \$2.53 in Norway compared with 97 cents in the United States and $\$ 1.23$ in Botswana. In Uganda, the price of gasoline per liter was $\$ 1.31, \$ 1.37$ in Kenya, \$1.42 in Tanzania, and 92 cents in Ghana (World Bank, World Development Indicators). Resistance to the temptation to divert part of the newfound oil to the domestic market to reduce energy prices at home - for example, to impress voters - signals a strong commitment to sound natural resource management and to socially efficient macroeconomic policies.

Rent seeking, especially when accompanied by ill-defined property rights, imperfect or missing markets, and lax legal structures, tends to divert resources away from more socially fruitful economic activity. This is where transparency can be helpful by increasing public awareness of counterproductive behavior patterns, thereby providing incentives for rent seekers to put their best foot forward. Recent international initiatives to raise transparency have proved encouraging in many countries, including: the Extractive Industries Transparency Initiative (EITI) which aims to set a global standard for transparency in oil, gas, and mining, the Revenue Watch Institute ( $\underline{\mathrm{RWI}})$ which promotes responsible management of oil, gas, and mineral resources, and the Natural Resource Charter ( $\underline{(N C)}$ ) which has set out principles for how to manage natural resources for development. Like Ghana and Tanzania, Uganda must become an EITI compliant country, meeting all the requirements in the EITI standard. According to Revenue Watch, Uganda needs to do more to promote transparency to "provide citizens with substantial amounts of information about revenue from the extractive sector." As of yet, Uganda has not been included in the Revenue Watch's Revenue Governance Index ( $\underline{\mathrm{RGI}})$, which measures the quality of governance in the oil, gas, and mining sectors of 58 countries, only eleven of which are reported to have satisfactory standards of transparency and accountability. The RGI scores and ranks countries based on a detailed questionnaire completed by researchers with expertise in the extractive industries, assessing the quality of four key governance components: Institutional and Legal Setting, Reporting Practices, Safeguards and Quality Controls, and Enabling Environment. The index also reflects information on state-owned companies, natural resource funds, and subnational revenue transfers; three special mechanisms commonly used to govern oil, gas and minerals. Opening the doors to, and collaborating with the aforementioned 
international non-government organizations is an essential aspect of the checks and balances needed to foster the best possible natural resource management regime.

Rent seeking is often closely linked to corruption, a serious issue in many resource-rich countries as evidenced by the corruption perceptions index issued by Transparency International, using a scale from one (corrupt) to 100 (clean). Of the 22 largest oil-producers around the world, only four (United States, United Kingdom, Canada, and Norway - the sole full-fledged democracies in the group) have corruption perceptions indices above 70, while the remaining eighteen countries range from sixteen (Iraq) to 69 (United Arab Emirates). A similar pattern is observed in the numbers reported recently by Gallup (2013). Asked in 2012 whether corruption is widespread throughout the government of their country, 25 percent of the roughly 1,000 adults aged fifteen years or older said Yes in Norway, 43 percent in the United Kingdom, 46 percent in Canada, and 73 percent in the United States compared with 62 percent to 92 percent for all other oil producing countries. Both sets of figures suggest that corruption generally thrives less well under democracy than under autocracy, presumably because democratic rule is more conducive to the establishment of institutional structures and mechanisms and international cooperation that restrain corruption (Gylfason, 2012). Without adequate checks and balances, despots usually find it more alluring than democrats to engage in corrupt practices, and often manage to do so with impunity. Even so, corruption is rampant in some democracies. Even before the advent of oil, corruption is a serious macroeconomic concern in Uganda, rated 26 by Transparency International, as compared to 27 for Kenya, 33 for Tanzania, and 46 for Ghana (higher scores suggest less corruption). Gallup projects a slightly different picture, reporting that 81 percent of Ugandans think that corruption is widespread throughout the government of their country compared with 93 percent in Kenya, 95 percent in Tanzania, and 89 percent in Ghana. These results bring home the crucial importance of transparency as an effective remedy against corruption in business and government, and its potentially corrosive effects on growth.

Figure 2 provides a snapshot of the cross-country evidence linking corruption to natural resources and economic growth in a large group of countries (an increase in the corruption perceptions index means less corruption, or more honesty; hence, the positive correlation between the corruption perceptions index and income shown in Figure 2 suggests that honesty is good for growth). ${ }^{5}$ Each country is represented by a bubble the size of which is proportional to the country's population in 2012, making China and India easy

\footnotetext{
${ }^{5}$ Depending on data availability, there is a slight variation in the number of countries covered by each chart in the text. Data for corruption and natural capital exist for 142 countries. Liberia and the Republic of Congo were not included in the left panel of Figure 2 because of their extremely high values for the natural capital share, well above $100 \%$. Natural capital estimates exist for 1995, 2000, and 2005.
} 
to identify in the figure. ${ }^{6}$ Notice that in the figure, and others to follow, Uganda is generally positioned close (and not too distant) from trend line.

Fig. 2. Corruption, Natural Capital, and Income

Natural capital and corruption

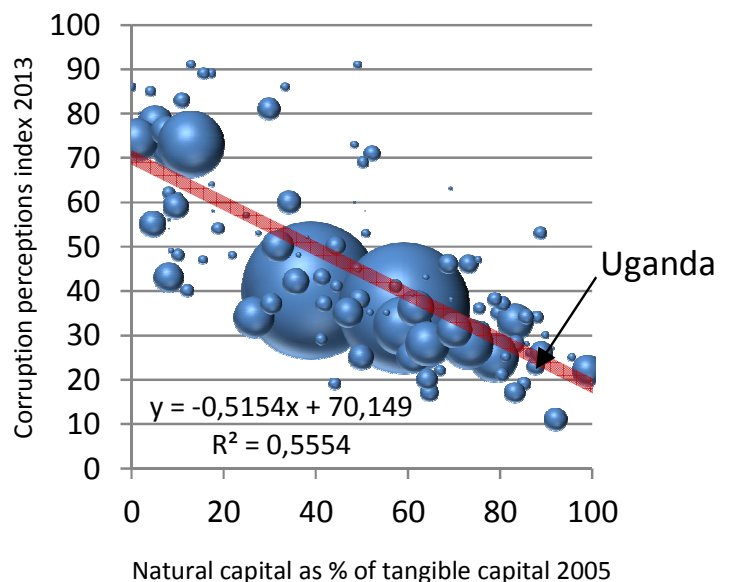

Corruption and income

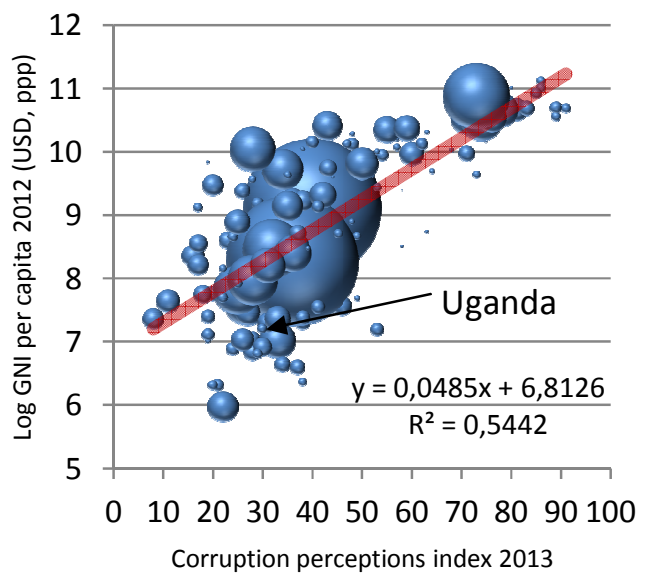

Source: Authors' computations based on World Bank, World Development Indicators, as well as updates of data in World Bank (2006) and data from Transparency International.

In the left panel of the figure, we see that corruption as measured by Transparency International in 2013 is directly correlated across 140 countries with the share of natural capital in tangible capital in 2005 (World Bank, 2006, as updated on the web). ${ }^{7}$ The Pearson correlation between the corruption perceptions index and the natural capital share is -0.75 . The slope of the unweighted regression line through the scatter on the left suggests an economically as well as statistically significant relationship between corruption and natural capital's share of tangible capital. This matters because corruption is inversely correlated to per capita GNI across the 151 countries shown in the rightmost panel where growth is represented by the log of purchasing power parity (PPP) of per capita GNI in 2012 on the grounds that the level of current income reflects its rate of growth in the past. The use of only the end-of-period value of per capita GNI for each country rules out reverse causation from growth to corruption. The Pearson correlation between corruption and income is significant at $\mathbf{0 . 7 4}$, a finding that corroborates the econometric results of Mauro

\footnotetext{
${ }^{6}$ We present each observation as a bubble proportional to country size rather than as a weightless dot, a practice originated by Fischer (2003). Like Fischer, we do this to allow the visual impression conveyed by the figure to reflect people rather than countries, giving larger weight to large countries than to small ones. Even so, the regression estimates presented are unweighted by population size. Throughout the paper, weighted regressions (not shown) would convey a similar qualitatitve pattern as the unweighted ones shown.

${ }^{7}$ Similar empirical patterns are observed if natural capital is measured by its share in total national wealth comprising tangible capital plus human capital rather than by its share in tangible capital, defined as the sum of real capital and natural capital. See World Bank (2006).
} 
(1995), among others. If countries could be viewed as moving up or down along the regression line, the slope of the line would suggests that a decrease in corruption by 40 points, corresponding roughly to the difference between Angola (23) and Botswana (64), would make per capita GNI rise by a factor of three, ceteris paribus. The effect would in fact be smaller than this because of the two-dimensional nature of the chart which does not reflect other relevant determinants of growth, thus assigning too much weight to the one determinant shown, corruption. The same caveat applies to the remaining bivariate correlations to be presented in what follows. Incidentally, in 2012 there was a threefold difference between purchasingpower-parity-adjusted per capita GNI in Botswana and Angola.

The take-away in this scenario is that if a large share of natural capital in total tangible capital creates temptations that prove conducive to corruption, and if corruption hurts growth, then this constellation of mechanisms may help explain part of the resource curse - that is, why a high natural capital share may be detrimental to growth.

\section{Two Dimensions of Diversification}

Specialization in production for export is one of the keys to realizing gains from domestic and foreign trade. However, there can be too much of a good thing, for two reasons. First, excessive specialization can increase risk. Should the specialized sector be hurt, if it is too dominant, its problems may then inflict extensive damage on the rest of the national economy, causing economic collateral damage. This is why economic diversification is a useful tool to mitigate risk. Second, the specialized sector needs to be one without significant adverse spillover effects on other sectors. No country has ever felt the need to diversify away from excessive reliance on human capital, but natural capital is another story. Its negative externalities are manifest in many countries, and include rampant rent seeking, environmental degradation, and repeated bouts of the Dutch disease.

As a general principle, diversification is good for growth, in part because it reduces risk of Dutch Disease. For example: economic diversification encourages efficiency and growth by channeling economic activity away from primary production in agriculture or excessive reliance on a few natural-resource-based industries, thus helping workers or their sons and daughters transfer from low-paying jobs in low-skillintensive farming or mining to more lucrative employment in more high-skill-intensive occupations in manufacturing and services. This is how countries become rich: technological advances release workers from agriculture, because in modern societies technological progress has meant that it takes only a tiny proportion of the work force to feed the population, a task that not so long ago occupied virtually the entire labor force.

As an example, South Korea's export-oriented diversification strategy helped catapult the country from rags to riches in 50 years, in stark contrast to the import substitution strategies followed by several Latin 
American countries which yielded less impressive results. In 1960, Korea's exports of goods and services amounted to three percent of GDP compared with eight percent in Argentina. In 2012, Korea's exports of goods and services amounted to 57 percent of GDP compared with 20 percent in Argentina. Further, manufactures constituted 85 percent of Korea's merchandise exports compared with 32 percent in Argentina. As a result, Korean manufacturers know how to produce things that households and firms in other countries demand, and today, the purchasing power of Korea's per capita GNI is more than twice that of Argentina.

The impressive record of Botswana is also relevant here. Botswana gained independence in 1966, having only twelve kilometers of paved roads, 22 college graduates, and 100 secondary-school graduates. Today, diamonds (discovered in 1967) provide tax revenue equivalent to 33 percent of GDP, giving Botswana Sub-Saharan Africa's highest per capita GNI. How did Botswana manage to achieve the world's highest rate of economic growth over the past 50 years? The short answer is good policies, good institutions, and democracy. Botswana assigned mining rights away from the tribes toward the state to head off tribal contestation for revenue, paid civil servants well, and hired foreign experts where needed (Gelb, 2011). Furthermore, Botswana has emphasized quality appraisals of public investment projects. Even so, Botswana's economy is not yet well diversified. In 2006, manufacturing accounted for only four percent of GDP while 30 percent of the work force remains in agriculture, which accounts for only two percent of GDP, suggesting low productivity in agriculture. Services, including government services, employ 55 percent of the labor force and account for 52 percent of GDP. Botswana spends more money on education relative to GDP and is less corrupt according to Transparency International than any other African country (Botswana 64, Mauritius 52).

Other relevant examples of diversification include Indonesia, where the authorities provided help to the low-cost textiles and footwear industry with good results; Thailand, which diversified its agriculture; Malaysia, which opened its arms to foreign direct investment to become a successful producer of manufactures, including electronic equipment and cars; and Chile, where the authorities encouraged farmers to branch out into wine and salmon production like New Zealand had done in the 1980s, also with good results. These examples of success suggest that industrial policy is not always doomed to failure (Rodrik, 2004). It is not true that industrial policy never works. It's true that picking winners seldom works, but even so, cutting losses can be fruitful. Industrial policy is prone to political capture and corruption, but so is privatization. Corrupt privatization is a symptom of corruption, not of privatization. The same applies to industrial policy. Generally, it pays to encourage new industries in line with the country's comparative advantages, and available expertise in public administration rather than try to break new ground; to follow the market rather than try to take the lead. A promising industrial policy strategy 
needs to be based on general principles and tailored to specific circumstances, not one-size-fits-all; simply more of the same is unlikely to succeed (Hausmann et al., 2014).

There is more to diversification than meets the eye. Economic and political diversification can be viewed as two sides of the same coin. Just as economic diversification spurs growth by transferring labor from low-paying jobs in low-skill-intensive farming and mining to more lucrative jobs in more high-skillintensive occupations, political diversification spurs growth by redistributing political power from narrowly based ruling elites to the people, giving way to political competition, democracy, and pluralism. Put differently, political diversification through democratization, exemplified by the promotion of electoral competitiveness, openness, and popular participation, can be viewed as an investment in social capital, including strong civil society, good governance, and societal institutions that people can trust (Paldam, 2000).

The essence of the argument is the same in both cases. Diversity pays by redistributing risk. Modern mixed economies need broadly based manufacturing, trade, and services to be able to offer the people steady improvements in their standard of living. An important part of a country's economic success is defined by its ability to produce goods and services that it can sell abroad - that is, goods and services that households and firms in other countries want to buy. Hence the need to find ways to diversify economic activity away from once-dominant agriculture that tends to keep the rural population in poverty and also from too much dependence on a few natural resources that sometimes but not always stifle or delay the advance of modern manufacturing and services. To function smoothly and grow at a rapid pace, national economies generally need broad political participation and a broad base of power in order to be able to offer all citizens an efficient and fair way of exercising their political will and civic rights through free elections, freedom of information, free assembly, and so on. Without political democracy, bad governments tend to become heavily entrenched, and the resulting damage becomes nearly insurmountable.

There is some evidence that the positive effects of democracy on long-run economic growth may outweigh the negative effects which may arise from political dissent derailing economic activity. The latter argument has been used in China and some other countries to this day, as in South Korea before the country became a democracy in the late 1980s (Gylfason, 2012). ${ }^{8}$ The need for diversification may be especially pressing in many resource-rich countries because they often face a double jeopardy - that is, natural-resource wealth being concentrated in the hands of small groups that seek to preserve their own privileges by opposing both economic and political diversification that would disperse their power and

\footnotetext{
${ }^{8}$ In an early econometric study, Helliwell (1994) found that while higher incomes helped democracy, the data did not allow him to conclude that more democracy was conducive to subsequent economic growth.
} 
wealth. Rent-seekers often resist reforms - economic diversification as well as democracy - that would redistribute the rents more evenly among the population (Auty, 2001; Ross, 2001).

The structure of exports with regard to manufactures and other products is important for long-run economic growth, among other things. The left panel of Figure 3 illustrates the strong inverse crosscountry relationship between manufactures exports, measured by the average share of manufactures in total merchandise exports (from 1962 to 2012) and natural capital in 126 countries (Pearson correlation = -0.82). In the right panel, growth is as before represented by the log purchasing power of per capita GNI in 2012 to rule out reverse causation from growth to manufactures exports. The relationship across 139 countries is significant in a statistical sense (Pearson correlation $=0.63$ ) as well as in an economic sense. The slope of the regression line (0.029) means that a twenty-point increase in the manufacturing share (e.g., from $40 \%$ to $60 \%$ ) goes along with an increase in real per capita GNI by well over a half (viz., by $58 \%)$.

Fig. 3. From Manufactures Exports to Growth

Natural capital and manufacturing

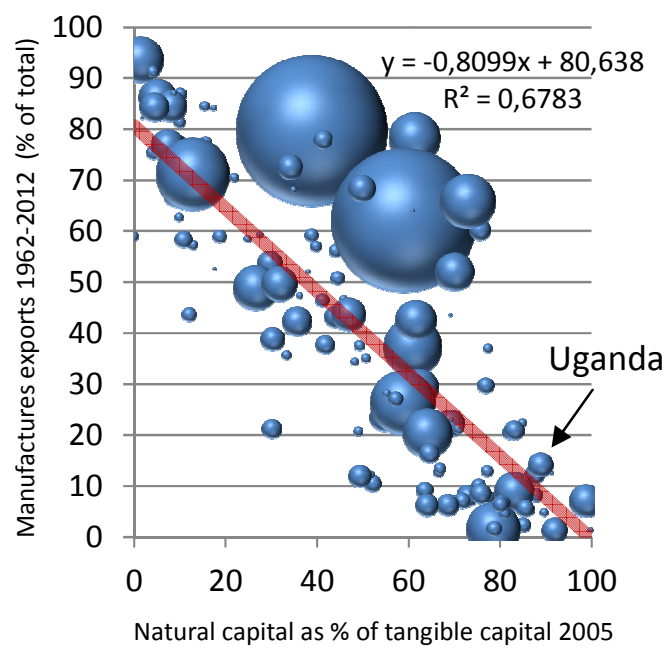

Manufacturing and income

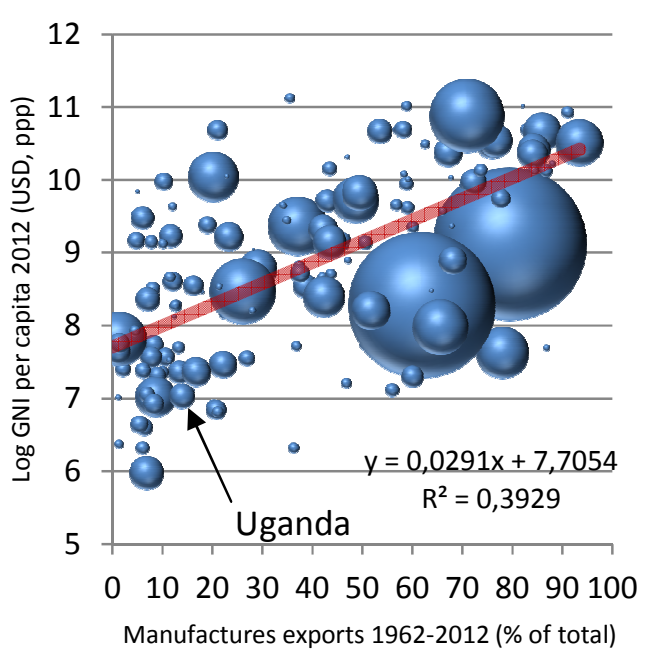

Source: Authors' computations based on World Bank, World Development Indicators, as well as on updates of data in World Bank (2006).

A similar pattern emerges if economic diversification is represented directly by the diversification of exports as measured by one minus the Herfindahl index, which shows whether the structure of exports by product of a given country differs from the world average. The index ranges from zero to one, with values closer to one indicating a larger difference from the world average. Hence, one minus the Herfindahl index rises with diversification. In Figure 4, the left panel shows an inverse cross-country relationship between export diversification on average from 1996 (the earliest year available from UNCTAD) to 2012 
and natural capital, measured as before in a group of 126 countries (Pearson correlation $=-0.70$ ). The right panel shows a strong positive link between export diversification and income per capita across 147 countries $($ Pearson correlation $=0.66)$. The slope of the regression line $(5.58)$ means that a 20-point increase in the export diversification index, corresponding roughly to the difference between Norway's 0.61 and Nigeria's 0.78 , would more than double per capita GNI.

\section{Fig. 4. From Export Diversification to Growth}

Natural capital and diversification

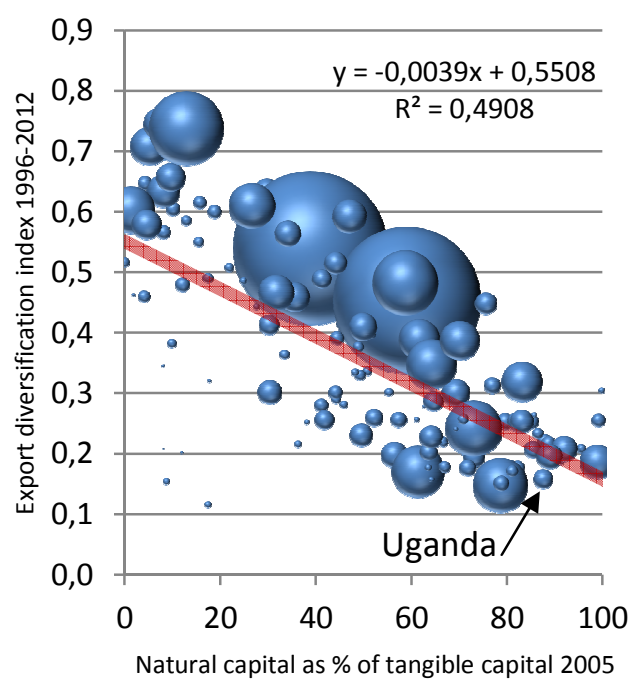

Export diversification and income

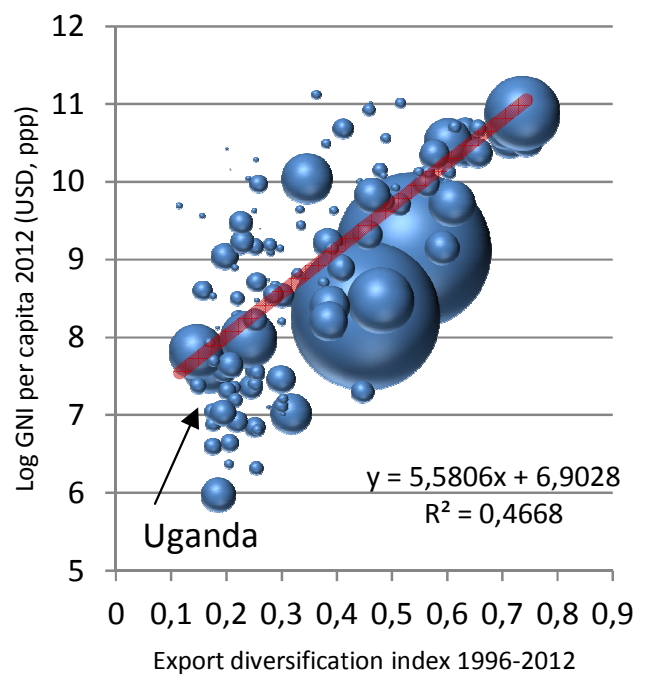

Source: Authors' computations based on World Bank, World Development Indicators, as well as on updates of data in World Bank (2006) and data from UNCTAD.

With expanding trade, economic diversification is on the rise around the world. In Sub-Saharan Africa, the share of manufactures in total merchandise exports increased from twelve percent in 1974 to 27 percent in 2012, which is down from 32 percent in 2002 (World Bank, World Development Indicators). In Latin America and the Caribbean, for comparison, the share of manufactures in total merchandise exports increased from eight percent in 1962 to 46 percent in 2012. Likewise, the world average share of manufactures in total exports rose from 59 percent to 69 percent over the same period (same source). In Uganda, the share of manufactures in total merchandise exports rose from two percent in 1994 to 34 percent in 2012, which is a good sign for growth. For comparison, the manufacturing share of exports in 2012 was 35 percent in Kenya, 25 percent in Tanzania, and nine percent in Ghana. Clearly, the composition of exports can be quite volatile, and volatility negatively impacts growth. 
Political diversification is also on the rise in Africa, where the number of autocracies has plunged since 1990 (Gylfason, 2013b). The left panel of Figure 5 illustrates the inverse cross-country relationship between democracy and natural capital in 123 countries (Pearson correlation $=-0.59$ ). Democracy is measured by the average of the Polity2 variable in each country over the sample period of 1960-2012, a variable that covers a spectrum of governing authority that spans from fully institutionalized autocracies through mixed, or incoherent, authority regimes to fully institutionalized democracies on a 21-point scale ranging from -10 (hereditary monarchy) to 10 (consolidated democracy). The rightmost panel of the figure illustrates the cross-country relationship between growth and political diversification through democracy in 139 countries from 1960 to 2012. As before, growth is represented by the log purchasing power of per capita GNI in 2012 to rule out reverse causation from growth to democracy. The relationship is significant in a statistical sense (Pearson correlation $=0.62$ ) as well as in an economic sense. The slope of the regression line (0.136) suggests that a six-point increase in Polity2 (e.g., from 0 to 6) would increase per capita GNI by about 80 percent. Democracy can be a powerful catalyst of growth, and so can high-quality leadership. Based on a new dataset on the education of public officials covering 178 countries from 1981 to 2011, Arezki et al. (2012) report a positive association between education attainment in public administration and government effectiveness (e.g., higher tax revenue mobilization, limiting corruption, better public finance management, and private market support).

Fig. 5. From Democracy to Growth

Natural capital and democracy

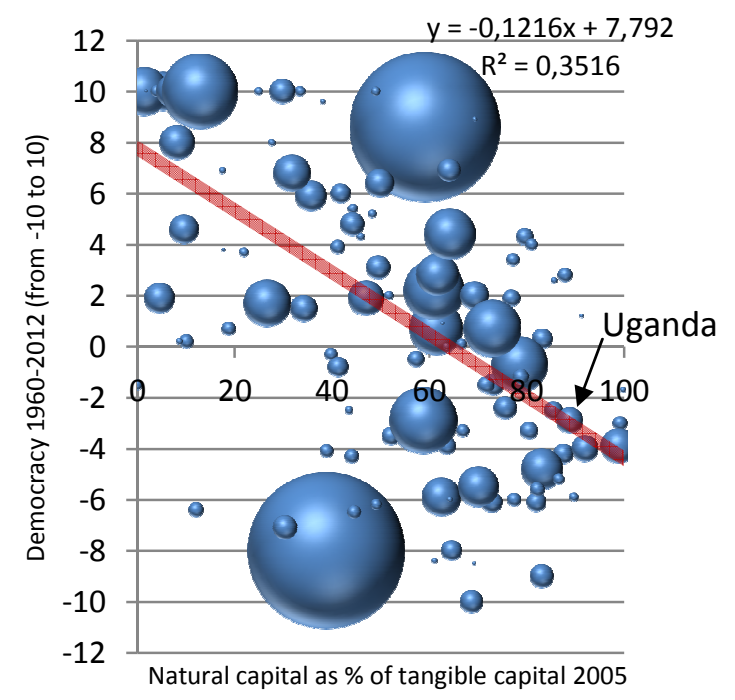

Democracy and income

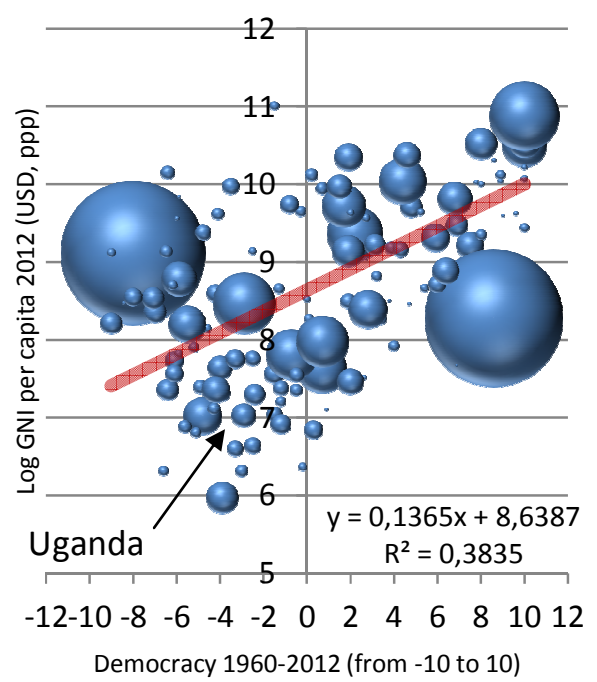

Source: Authors' computations based on World Bank, World Development Indicators, as well as on updates of data in World Bank (2006) and data from the Polity IV Project. 
Fig. 6. Recap: From Double Diversification to Growth

Diversification and income

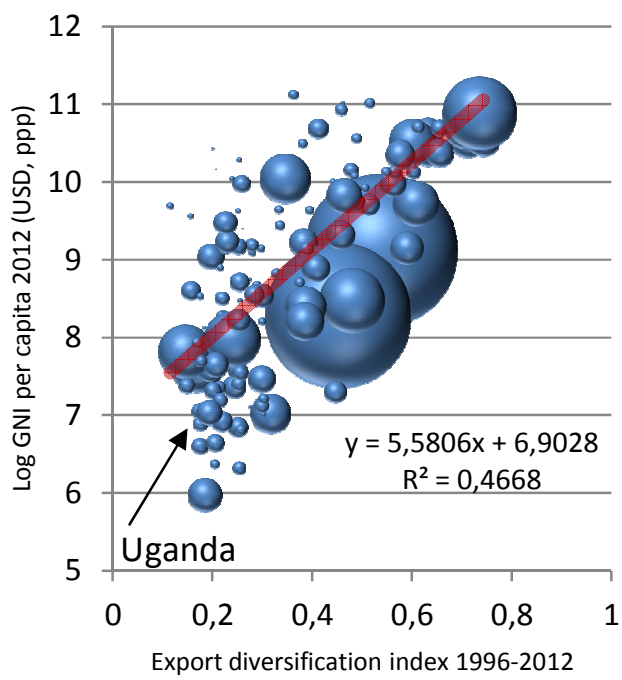

Democracy and income

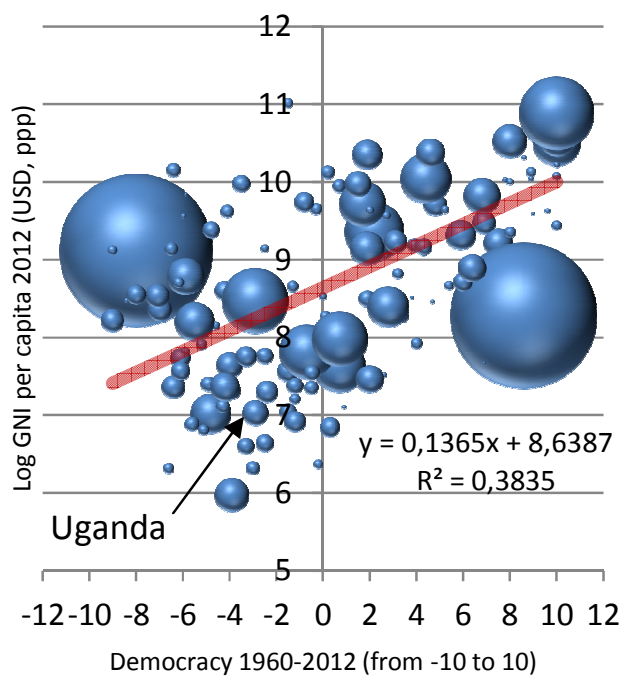

Source: Figures 4 and 5.

Notice the resemblance between the right panels in Figures 4 and 5, shown again side by side in Figure 6 . Economic diversification and political diversification are both good for growth and they go hand in hand across countries whether economic diversification is measured by the share of manufactures in total merchandise exports or by the Herfindahl export diversification index (Figure 7).

\section{Fig. 7. Complementarities}

Democracy and manufacturing

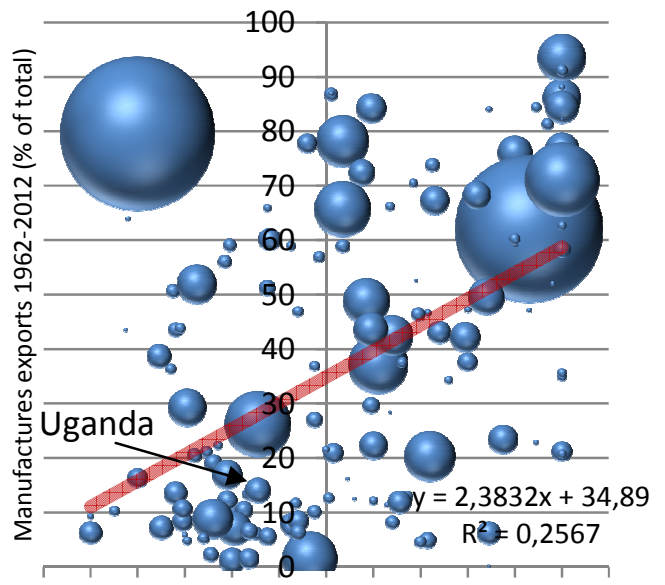

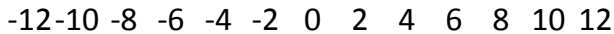
Democracy 1960-2012 (from -10 to 10)
Democracy and diversification

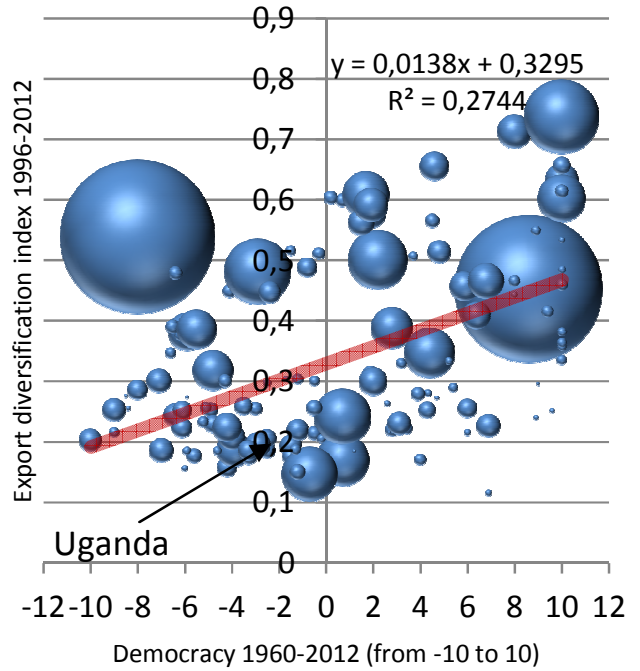

Source: Authors' computations based on World Bank, World Development Indicators, as well as on data from UNCTAD and the Polity IV Project. 
Fig. 8. Further Complementarities

Democracy and corruption

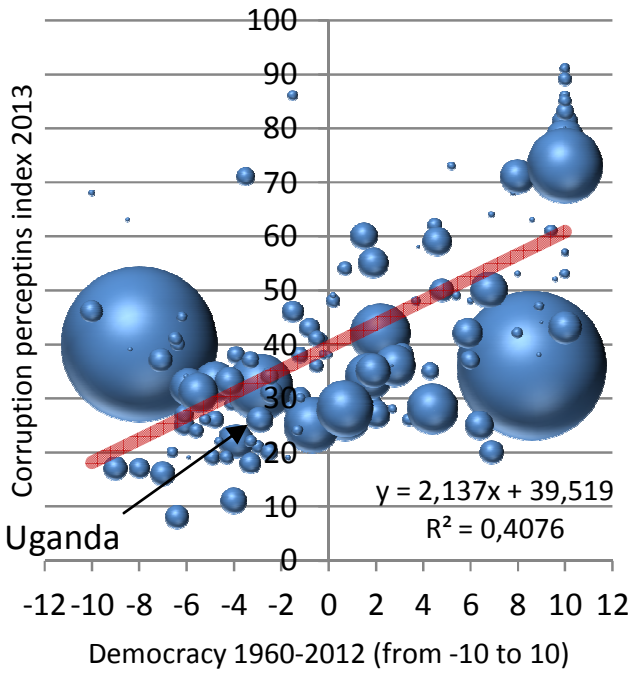

Diversification and manufacturing

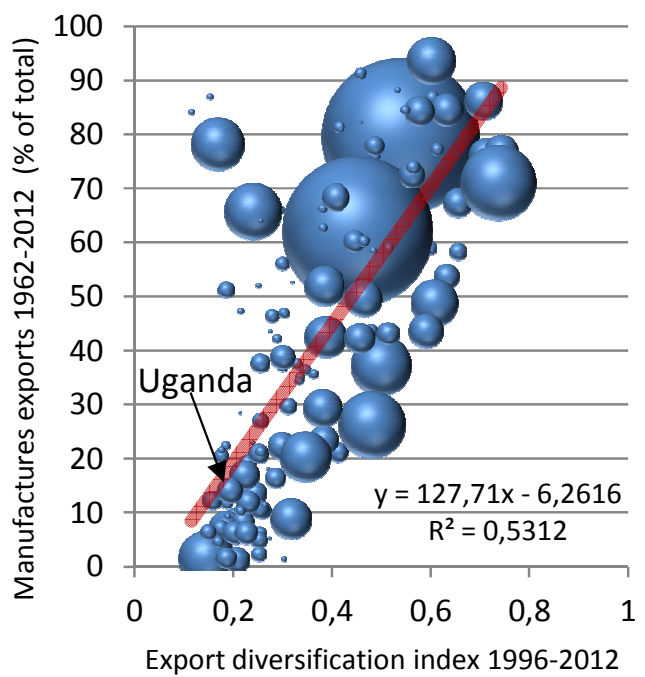

Source: Authors' computations based on World Bank, World Development Indicators, as well as on data from Transparency International, UNCTAD, and the Polity IV Project.

In Figure 7, the Pearson correlation between the share of manufactures exports in total merchandise exports and democracy is 0.51 (143 countries), and between the export diversification index and democracy is 0.52 (142 countries). If the absence of democracy enables rent seekers to hold back economic as well as political diversification, the advance of democracy - that is, political diversification seems likely to create conditions for economic diversification, among other things. The left panel of Figure 8 shows how democracy and low corruption go hand in hand across countries (Pearson correlation $=0.64,141$ countries). The relationship works both ways: democrats are less likely than autocrats to tolerate high levels of corruption. Corrupt rulers typically resist democracy, and may use low taxes and generous transfers and subsidies to weaken popular demand for democracy, even if they amount to only a small fraction of each citizen's fair share of the nation's oil wealth. Democratization through institutional reform and the fight against corruption can be viewed as complementary investments in social capital. The right panel of Figure 8 illustrates the fairly close correspondence between manufactures exports and export diversification (Pearson correlation $=0.73,140$ countries).

Taken together, Figures 2 through 5 suggest a qualitative pattern even if the quantitative slopes of the regression lines need to be interpreted with care. In summary: first, if a high share of natural capital in total tangible capital tends to go along with corruption, and if corruption is bad for growth, we have identified a channel through which a high natural capital share may (if left unattended) slow down growth 
(Figure 2). Second, if a high natural capital share discourages manufactures exports and export diversification, and if manufactures and diversification are good for growth, then we have an additional channel through which a high natural capital share may slow down growth (Figures 3 and 4). Third, if a high share of natural capital tends to weaken democracy and if democracy is good for growth, then we have yet another channel through which a high natural capital share may hurt growth (Figure 5).

Fig. 9. Natural Capital and Income per Capita

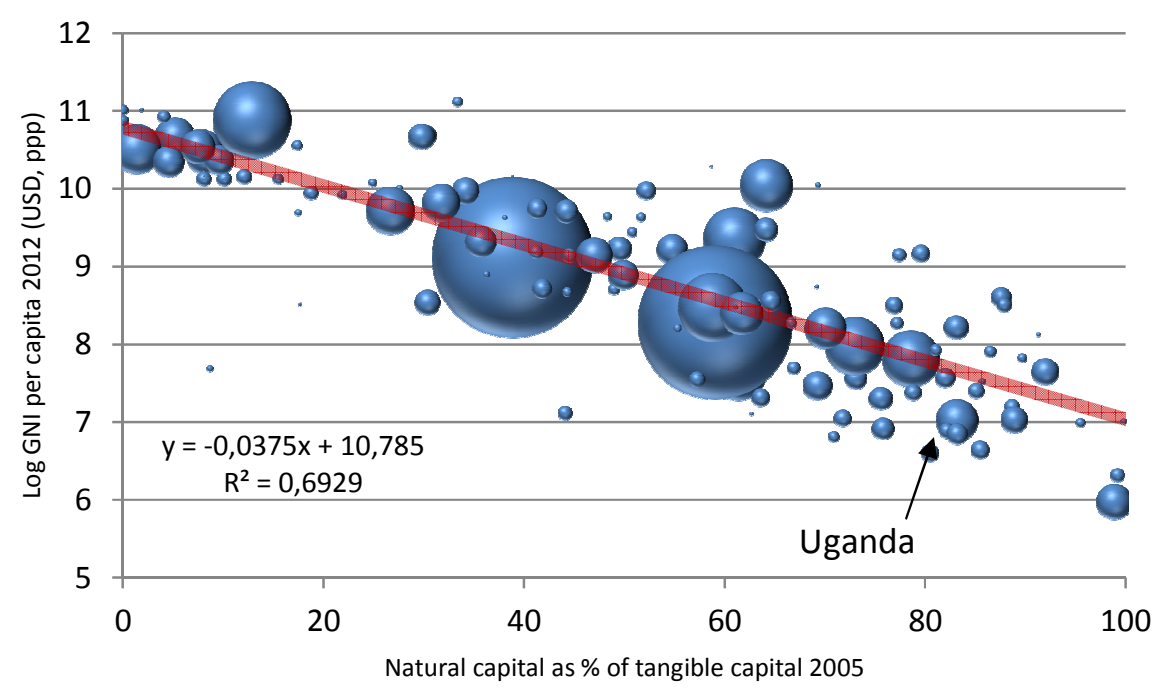

Source: Authors' computations based on World Bank, World Development Indicators, as well as on updates of data in World Bank (2006).

When these possibilities are considered along with various other forms of rent seeking as well as the Dutch disease, plus the possibility that natural resource wealth may weaken incentives to build up human as well as social capital (Gylfason, 2001), it is not surprising to see a fairly strong inverse relationship between natural capital and economic growth across the 129 countries for which we have data on both variables, with a Pearson correlation of -0.83 (Figure 9). If taken at face value, the slope of the regression line (-0.038) means that a 30-point decrease in the natural capital share, corresponding to the difference between India's 0.59 and Uganda's 0.89, would more than double per capita GNI.

\section{Natural Resource Ownership and Constitutions}

To be efficient and fair, the utilization of oil and other natural resources requires that the right owners the people or the state on their behalf - be appropriately compensated. By international law, the property rights to natural resources belong to the people. Article 1 of the International Covenant on Civil and 
Political Rights (ICCPR) states the following: “All people may, for their own ends, freely dispose of their natural wealth and resources." The ICCPR was adopted in 1966 to fortify the United Nations Human Rights Declaration from 1948. Its purpose is to rule on effective remedies for victims of human rights violations. The ICCPR has 165 signatories. The non-signatories are China, Cuba, Malaysia, Pakistan, Saudi-Arabia, Singapore, and Vatican City in addition to some other small countries.

A people's right to their natural resources is proclaimed in primary documents of international law, and enshrined in many national constitutions. Violations of this universal principle of equality and human rights bring legal and constitutional issues into the picture. Most constitutions declare that all citizens are equal before the law, ruling out discrimination among individuals on any basis. This must naturally be understood to include a prohibition against unequal or discriminatory access to common property resources. Strikingly, Article 244 of the constitution of Uganda reads: "All minerals and petroleum in Uganda are held by the Government on behalf of the people of Uganda." Several other constitutions (Angola, Azerbaijan, Chile, China, Ghana, Iraq, Kazakhstan, Kuwait, Nigeria, and Russia, to name a few) likewise stipulate that natural resources belong to the people or the state; some more clearly than others. Nigeria's constitution, like that of Russia, is rather vague on this point, stating in Article 16 that "[t]he State shall direct its policy towards ensuring ... that the material resources of the nation are harnessed and distributed as best as possible to serve the common good." By Article 9 of the Russian constitution: "The land and other natural resources may be in private, state, municipal and other forms of ownership."

There is an important distinction to be made between state ownership and national ownership. Such a distinction is made clear in the constitutional bill set before the Icelandic parliament (Gylfason, 2013a). The bill was approved by 67 percent of the voters in a national referendum in October 2012, and the provision declaring natural resources not in private ownership to be the perpetual property of the nation was approved by 83 percent of the voters. The difference is as follows. State ownership (e.g., public office buildings) means that the state can sell or pledge such assets at will. National ownership (e.g., cultural assets like the Taj Mahal and the pyramids or natural assets like fish and energy) is another story. National ownership means that the state cannot sell or pledge such assets because they are considered invaluable and irreplaceable. This means that losing them would constitute a violation against, for example, the rights of the current generation's descendants who might later realize that their parents' generation had plundered the nation's common heritage. The current generation inherited the nation's natural resources from earlier generations, and must preserve them and their earning potential for future generations in the spirit of sustainable development. The argument applies especially to renewable resources subject to the somewhat paradoxical qualification that renewable resources around the globe sometimes seem to face a greater threat of depletion than do nonrenewable resources, and likewise to cultural assets of historical value. The current generation does not have the right to squander them any 
more than it has the right to solve its current fiscal problems by selling precious cultural assets - Greek islands, anyone? - or by ruining the natural environment.

The parallel between natural and cultural assets is one source of the link between natural resources and human rights. Another source, in some cases, is unequal access to the revenues and rents from natural resources. In 2007, this led the United Nations Human Rights Committee to issue a binding opinion declaring the Icelandic system of fisheries management (by which select vessel owners are granted privileged access to common-property fishing grounds) to be discriminatory and thereby unconstitutional. Thus, the committee instructed the government to rectify the system by removing the discriminatory element from the system as well as paying damages to the two fishermen plaintiffs. This 2007 opinion of the UNHRC has far-ranging implications for natural resource management around the world. Expropriation of common property natural resource rents under a veil of secrecy is equivalent to selling other people's assets.

Wenar (2008) makes essentially the same point about oil and other mineral resources, except in the United States, Canada, and Australia, where rights to oil resources were legally transferred to private companies; natural resources, as a rule, are common property resources. This means that, by law, the resource rents ought to accrue in large part to the government. Hence, no taxation is really needed except as a formality, although the word 'tax' would be inappropriate; 'fee' is a more appropriate word, as fees are typically levied in exchange for providing specific services - such as permission to utilize a common property resource. Accordingly, resource taxes should rather be referred to as fees or resource depletion charges (Gylfason and Weitzman, 2003). In any event, it is important to use the proceeds from resource fees either to finance socially productive expenditures, or to reduce other less efficient sources of public revenue to keep the overall tax burden manageable. Good fiscal governance requires careful attention to allocative as well as technical efficiency on both sides of the fiscal equation; public expenditures, as well as the revenue mobilization needed to finance those expenditures.

\section{Distributive options of natural resource wealth}

There are three basic ways of efficiently distributing common property resource rents to a nation's citizens. A similar issue arises in the context of privatization of state property and how to maximize the revenues of the rightful owners. One way forward is through fees or royalties that the fiscal authorities can use to finance public spending or reduce taxes - or stow away as did Norway. The challenge of finding the right fee is comparable to that of pricing electricity or other utilities; it must be done by trial and error. A second way forward is through auction, where potential users of the resource bid for the right of use on a level playing field, and thus maximizing the revenue that will accrue to the owners. A third method is to issue vouchers, or transfer cash/checks to every eligible citizen as has been done in Alaska for some time. Under ideal conditions, the efficiency properties of these three methods are analytically 
equivalent as long as the agreed goal is to maximize the revenue of the owner. Failure to use one of these methods, or a combination of them is common, and is tantamount to a subsidy to those who are granted access to the resources, inviting inefficiency and favoritism.

Some observers mistrust the first two methods (fees and auctions) on the grounds that they risk granting too much revenue and too much power to the government. These observers advocate instead that oil revenues be transferred as directly as possible to the private sector, safely bypassing the government's coffers (Sala-i-Martin and Subramanian, 2013). The private sector is not infallible, either. Rather than privatizing natural resources, therefore, it is possible to outsource - that is, depoliticize - their management by granting independent yet democratically accountable experts a say in their management (Gylfason and Weitzman, 2003). This is how the judicial system and, more recently, central banking has been outsourced in many countries to safeguard the integrity of justice, and of the currency by keeping politicians at arms' length. Foreign central bank governors and monetary policy committee members are increasing in number in several countries, from Botswana and Mauritius to the United Kingdom.

However, if the privatization route is taken, it makes a difference to whom the oil rent is transferred. If the rent is divided evenly among the adult population as in Alaska, the allocation can be deemed fair if not necessarily efficient. If, on the other hand, the resource rent is granted to select interested parties, the allocation fails both the fairness and efficiency tests and produces an economic and political oligarchy with intensified regulatory and rent capture as a result. This was the case in Iceland where fishing quotas were handed virtually free of charge to boat owners. Many countries succumb to such a state of affairs because the stakes can be huge, and the will to resist is weak and dispersed.

The legal aspect of natural resources as human rights has an important implication. The accrual of natural resource rents to the government presupposes representative democracy and hence, as a matter of international law, the legitimacy of the government's right to dispose of the resource rents on behalf of its people (Wenar, 2008). ${ }^{9}$ The expropriation of common property resources, and the revenues they generate, by political or business elites is against international law. These elites are lacking legitimacy that is firmly grounded in democratic institutions and practices. Domestic laws, including constitutions, need to reflect this fact to reinforce the legal recourse of those citizens who might want to challenge in court, allegedly unlawful expropriation of natural resource rents, because every citizen has the same right to the benefits that flow from common property resources.

Frédéric Bastiat (1850) would not have been surprised:

"Sometimes the law defends plunder and participates in it. Thus, the beneficiaries are spared the shame and danger that their acts would otherwise involve ... But how is this legal plunder to be identified? Quite

\footnotetext{
${ }^{9}$ By international law, this proclamation presupposes political diversification through representative democracy. Common property resources, by law, are not empty words.
} 
simply. See if the law takes from some persons what belongs to them and gives it to the other persons to whom it doesn't belong. See if the law benefits one citizen at the expense of another by doing what the citizen himself cannot do without committing a crime. Then abolish that law without delay - No legal plunder; this is the principle of justice, peace, order, stability, harmony and logic... The war against illegal plunder has been fought since the beginning of the world. Long before the Revolution of February 1848 long before the appearance even of socialism itself - France had provided police, judges, gendarmes, prisons, dungeons, and scaffolds for the purpose of fighting illegal plunder. The law itself conducts this war, and it is my wish and opinion that the law should always maintain this attitude toward plunder."

\section{The Norwegian Story}

From the beginning, the oil and gas reserves within Norwegian jurisdiction were defined by law as common property resources, thereby clearly establishing the legal rights of the Norwegian people to the resource rents. On this legal basis, the government has absorbed about 80 percent of the resource rent over the years, setting most of its oil revenue aside in the state petroleum fund, which was recently renamed "The Norwegian Pension Fund" to reflect its intended use. At nearly USD 900 billion (equivalent to more than USD 190,000 per Norwegian citizen) the Norwegian Pension Fund is currently the world's largest Sovereign Wealth Fund.

At the outset, in 1971, the Norwegian parliament laid down economic and ethical principles ('commandments') to guide the use and exploitation of the oil and gas for the benefit of current and future generations of Norwegians. There is, however, not a word about natural resources in Norway's constitution. The risk of rent seeking or undue expropriation never surfaced. It likely helped that Norway was already a mature and fully-fledged democracy. Norway has displayed only vague symptoms of the Dutch disease, including the nonexistence of world famous Norwegian high-tech companies akin to Denmark's Bang \& Olufsen, Finland's Nokia, and Sweden's LM Ericsson next door. Another possible symptom is Norway's unwillingness, almost unique among European nations, to join the European Union and the Economic and Monetary Union.

In anticipation of increased statutory Central Bank independence in 1999, to immunize monetary policy from political influence, the management of the oil fund was shifted from the Ministry of Finance to the Central Bank in 1997. The aim of outsourcing the oil fund's management to the Central Bank was to immunize the management of the fund from political interference by increasing the distance between politicians and the oil wealth, and thus encouraging pluralism, and keep away from conflicts of interest. Some countries have followed Norway's example. Azerbaijan went a step further by establishing its State Oil Fund in 1999 as an independent legal entity whose role is to manage the country's oil revenues. The Russian National Fund was established as a stabilization fund in 2004 and then changed in 2008 to a 
Sovereign Wealth Fund which, in contrast to the Norwegian formula, is controlled by the Ministry of Finance. Norway differs from most other major oil producers in that its oil wealth is estimated to amount to only about four percent of Norway's total national wealth, the bulk of which (88 percent according to the Norwegian Ministry of Finance) consists of human capital. In Norway, broad political consensus was reached on the oil wealth management strategy, as the main political parties have shared an understanding from the beginning that the national economy needs to be shielded from an excessive influx of oil money to avoid overheating and waste. The Norwegian oil fund is a net fund with no liabilities. Money accumulates in the fund every year on a net basis after the government budget is balanced.

In its role as guardian of the people, the Norwegian government has kept a tight grip on the country's oil wealth by setting up a governance structure intended to safeguard the resource rent from political interference. Norway can afford to be patient. Clearly, with pressing economic and social needs, Uganda cannot be expected to show the same patience as the Norwegians. Even so, Uganda can learn from Norway and other countries about how best to build up governance structures designed to separate the management of its oil wealth from short-term political pressures. Insofar as extracted oil wealth is held abroad as in Norway, it can be kept in three types of sovereign wealth fund which may all be important in promoting diversification (van der Ploeg and Wills, 2014): (i) A future generations fund aiming to replace a sharp temporary appreciation of the currency in real terms during the boom with a moderate permanent appreciation; (ii) a volatility/income stabilization fund aiming to prevent sharp hikes in the currency during short-term oil price booms; and (iii) a parking fund (for limiting absorption constraints) that aims to avert large price and wage increases in the construction sector. Investing abroad gives time to consider what investments should be undertaken domestically, i.e., to use the global capital market to separate the decision to extract oil from the decision of spending the proceeds.

\section{Concluding Remarks}

The need to develop a strategy to sustainably transform natural capital into human capital and social capital is evident even if the road map on the table remains somewhat unclear. In other words, there is no one-size-fits-all blueprint available to guide Uganda or other countries to a sustainable path of successful economic diversification and growth.

It seems natural to conclude from other countries' experiences that what is good for growth is generally conducive to economic diversification. The build-up of human resources through education and training is good for growth, and also for diversification since manufacturing and, especially, many modern services depend on a well-educated labor force. Education and job training are always beneficial and desirable, and should therefore always be a high priority in all forms. This is even more relevant for a country like 
Uganda where only 20 percent of the labor force has completed at least secondary education, compared with 50 percent in Ghana (Figure 10).

Fig. 10. Education Attainment of Labor Force

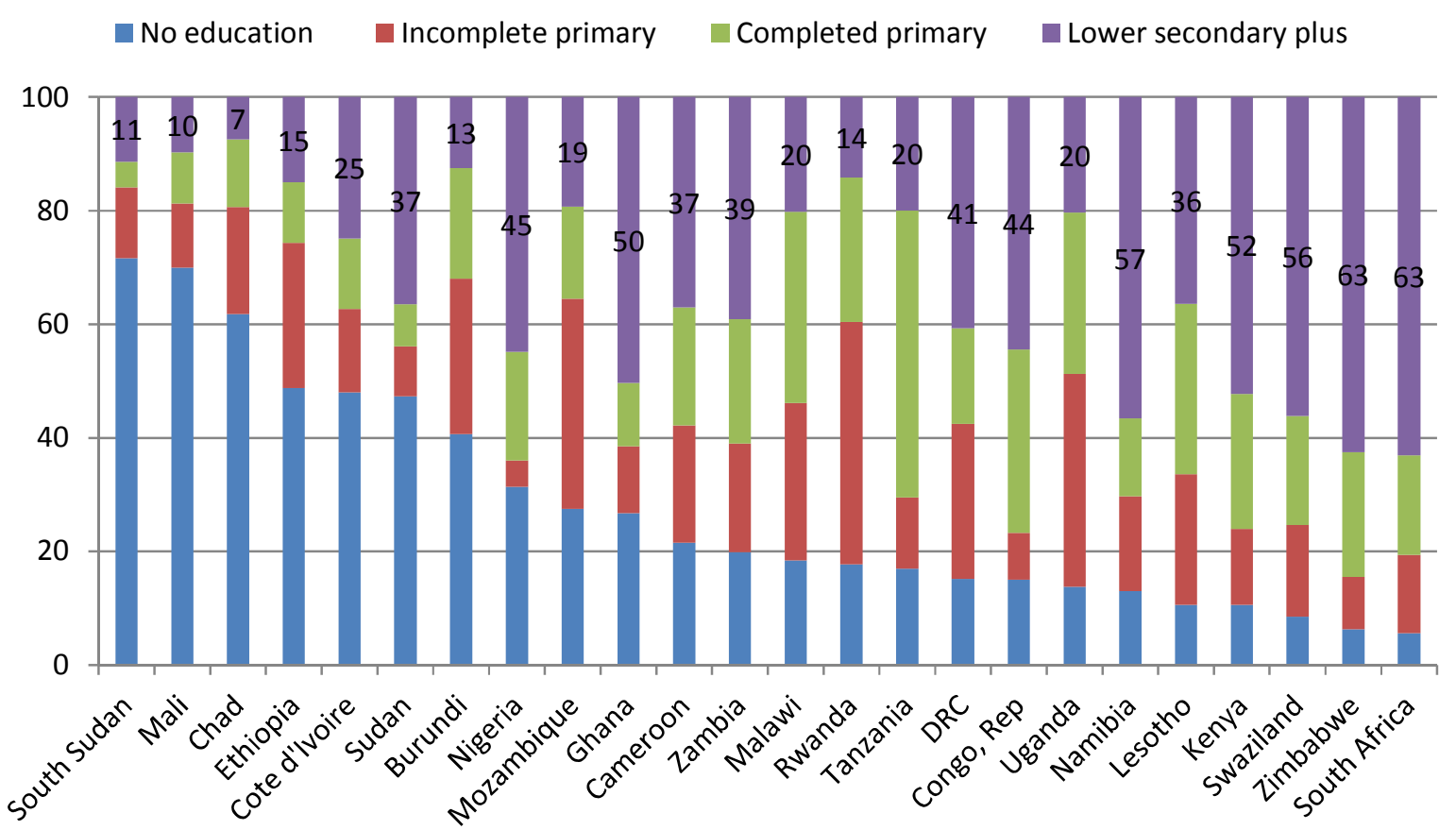

Source: Uganda Bureau of Statistics.

Moreover, UNESCO's school life expectancy ${ }^{10}$ for Uganda is eleven years (as in Kenya), compared with twelve years in Tanzania, Ghana, and Botswana; fourteen years in Mauritius, and seventeen years in the United Kingdom. The same argument applies to the construction of essential infrastructure - schools, hospitals, roads, bridges, telecommunications facilities, and electrification - that passes the test of benefitcost appraisals: it is always good for growth and generally helps promote a wide range of economic activities. In keeping with the principle that diversification along existing lines of comparative advantage is more likely to succeed than entering unknown territory, construction of oil pipelines and technical assistance to less experienced oil and gas producers has worked well for Norway, whose Statoil operates in over 30 countries around the world.

Generally, investment in social capital, including sound institutions that people can trust, as well as good governance, is important in itself, benefits to growth and diversification notwithstanding. The Legatum

\footnotetext{
${ }^{10}$ School life expectancy from UNESCO is the total number of years of primary to tertiary schooling that a child can expect to receive, and can be taken as a proxy for the evolution of educational attainment over time because the advance of school life expectancy is a gradual process.
} 
Institute has recently published a comprehensive prosperity index, designed to include subjective dimensions such as trust and transparency in an overall assessment of prosperity. Comprised of eight different categories including Economy, Entrepreneurship and Opportunity, Governance, Education, Health, Safety and Security, Personal Freedom, and Social Capital, the prosperity index suggests that in Uganda, 34 percent of those surveyed have confidence in the judicial system. This is compared with 48 percent in Kenya, 41 percent in Tanzania, 75 percent in Ghana, and 82 percent in Botswana. At 41 percent, confidence among Ugandans in their government is about the same as in Kenya and Tanzania, but less than in Ghana (75 percent) and Botswana (69 percent). Trust is important. Public and private investments in human and social capital, including trust, need to be given high priority to foster both diversification and growth.

Foreign trade and investment benefit diversification and growth as illustrated by the examples of Mauritius and South Korea, among others. One reason for this is that foreign and domestic competition helps make domestic producers more competitive. In brief, the promotion of competition, domestic as well as foreign, encourages efficiency, diversification, and growth. But this is not always easy to accomplish, because those who benefit from barriers to trade and competition (such as cartels), may resist liberalization. Another time-honored way to promote growth is through regional trade initiatives as exemplified by the East African Community. This is a fully-fledged customs union comprising Burundi, Kenya, Rwanda, Tanzania, and Uganda. Like charity, trade promotion begins at home.

With so many issues to be addressed to promote diversification and growth, there is no presumption that some things ought to be prioritized. In other words, there is no presumption derived from theory or country experiences that any particular sequencing of actions is to be preferred. This means that, as a practical matter, it may be advisable to seek the path of least resistance, doing the easy things first; climbing up the ladder rim by rim. This approach suggests that as oil revenue begins flowing in, a big effort to boost education, infrastructure, and institution building, including good governance, subject case by case to benefit-cost analysis, ought to be given high priority, since such efforts are not likely to generate much opposition. Such efforts can be driven by the government or by the private sector with government encouragement and support, or by autonomous oil funds. The promotion of free trade, competition, and full transparency may be harder to accomplish amongst strong political opposition, and should probably not be attempted up front in such instances.

Exchange rates also have an important part to play. While depreciating currencies accompanied by inflation can be an important catalyst of currency unions as, for example, in Europe and parts of Africa, overvalued and volatile currencies accompanied by slow export diversification and sluggish growth can also constitute a potentially important justification for fixing exchange rates through currency unions in natural resource rich economies. In countries prone to the Dutch Disease, a currency union requires 
flexible fiscal and structural adjustment facilitating vivacious export activity in lieu of nominal currency appreciation aiming to contain inflation at the cost of stagnant non-resource exports. Even so, real exchange rates always float through domestic and foreign price adjustment regardless of nominal exchange arrangements. These considerations need to enter into existing plans for currency cooperation within the East African Community.

Sovereign wealth funds can play an important role in the process of economic diversification by protecting the management of oil revenues from the vicissitudes of the political process and by resisting short-sighted political demands for cash injections into the government's coffers to meet current needs. Clearly, with its modern infrastructure, Norway can afford to be patient and to stash away virtually all of its oil revenues in foreign accounts for future use, thus using the interest earned to finance future pensions while keeping the principal intact. In view of their more pressing needs, emerging countries cannot be expected to show such patience; it is more natural to use some of the oil revenues to finance investments in human and social capital, and infrastructure, and to save the rest for future use through sovereign wealth funds (Collier, 2012).

\section{References}

Aghion, Philippe, and Abhijit Banerjee (2005), Volatility and Growth, Oxford University Press, Oxford and New York.

Aguinaga, Paulina, Charles Ncho-oguie, and Jean-Pascal N. Nganou (2014), "Review of Oil-Price Subsidies: Lessons for Uganda," Working Paper (forthcoming).

Ampratwum, Edward Fokuoh, and Maxwell Agyei Ashon (2012), "Governance in Africa‘s Oil and Gas Exporting Countries: Evidence from the Ibrahim Index of African Governance," Ghana Center for Democratic Development Briefing Paper, Vol. 10, No. 4, May.

Andrews, Matt, and Lawrence Bategeka (2013), ”Overcoming the Limits of Institutional Reform in Uganda,” ESID Working Paper No. 27, ESID Policy Paper No. 1, November.

Arezki, Rabah, and Thorvaldur Gylfason (2011), "Commodity Price Volatility, Democracy and Economic Growth," in de La Grandville, Olivier (ed.), Frontiers of Economic Growth and Development, Emerald.

Arezki, Rabah, Herbert Lui, Marc Quintyn, and Frederik Toscani (2012), "Education Attainment in Public Administrations around the World: Evidence from a New Dataset," IMF Working Paper WP/12/ 231, September.

Auty, Richard M. (2001), "The Political Economy of Resource-Driven Growth," European Economic Review 45, May, 839-846.

Bastiat, Frédéric (1848), Economic Sophisms, 2nd series, Ch. 1, Physiology of plunder. 
Bastiat, Frédéric (1850), The Law.

Bremer, Ton S. van den, and Frederick van der Ploeg (2013), "Managing and Harnessing Volatile Oil Windfalls,“IMF Economic Review 61, No. 1, 130-167.

Collier, Paul (2011), The Plundered Planet: Why We Must - and How We Can - Manage Nature for Global Prosperity, Oxford University Press, Oxford and New York.

Fischer, Stanley (2003), “Globalization and Its Challenges,” American Economic Review 93, No. 2, 1-30.

Frankel, Jeffrey (2011), “A Solution to Fiscal Procyclicality: The Structural Budget Institutions Pioneered by Chile," Fiscal Policy and Macroeconomic Performance, Fourteenth Annual Conference of the Central Bank of Chile. NBER WP No. 16945.

Frankel, Jeffrey (2012), "Mauritius: African Success Story," CID Working Paper No. 234, April, forthcoming in Edwards, Sebastian, Simon Johnson, and David Weil (eds.), African Successes.

Gelb, Alan (2011), "Economic Diversification in Resource-Rich Countries," Ch. 4 in Arezki, Rabah, Thorvaldur Gylfason, and Amadou Sy (eds.), Beyond the Curse: Policies to Harness the Power of Natural Resources, International Monetary Fund, Washington, DC.

Gylfason, Thorvaldur (2001), "Natural Resources, Education, and Economic Development," European Economic Review 45, May, 847-859.

Gylfason, Thorvaldur (2012), "Development and Growth in Resource-Dependent Countries: Why Social Policy Matters,“ Ch. 2 in Hujo, Katja (ed.), Mineral Rents and the Financing of Social Policy: Opportunities and Challenges, Palgrave, United Kingdom.

Gylfason, Thorvaldur (2013a), "From collapse to constitution: The case of Iceland," in Paganetto, Luigi (ed.), Public Debt, Global Governance and Economic Dynamism, Springer.

Gylfason, Thorvaldur (2013b), "Democracy in Africa," Vox, 17 November.

Gylfason, Thorvaldur, and Martin Weitzman (2003), "Icelandic Fisheries Management: Fees vs. Quotas," CEPR Discussion Paper No. 3849, March.

Gylfason, Thorvaldur, and Gylfi Zoega (2003), "Inequality and Economic Growth: Do Natural Resources Matter?," in Theo Eicher and Stephen Turnovsky (eds.), Inequality and Growth: Theory and Policy Implications, MIT Press.

Gylfason, Thorvaldur, and Gylfi Zoega (2006), "Natural Resources and Economic Growth: The Role of Investment," World Economy 29, No. 8, August, 1091-1115.

Hausmann, Ricardo, John Matovu, Rosie Osire, and Kelly Wyett (2014), "How should Uganda grow?", ESID Working Paper No. 30, ESID Policy Paper No. 2, January.

Helliwell, John F. (1994), "Empirical Linkages between Democracy and Economic Growth," British Journal of Political Science 24, No. 2, April, 225-248. 
Henstridge, Mark, and John Page (2012), "Managing a Modest Boom: Oil Revenues in Uganda," OxCarre Research Paper 90.

King, Robert G., and Ross Levine (1993a), "Finance and Growth: Schumpeter Might be Right," Quarterly Journal of Economics 108, August, 717-737.

King, Robert G,. and Ross Levine (1993b), "Finance, Entrepreneurship and Growth: Theory and Evidence," Journal of Monetary Economics 32, 513-542.

Krueger, Anne (1974), "The Political Economy of the Rent-Seeking Society," American Economic Review 64, No. 3, 291-303.

Matovu, John and Jean-Pascal N. Nganou (2014), "Fiscal Policy stance, Oil revenues, Growth and Social Outcomes for Uganda," Working Paper (forthcoming).

Mauro, Paolo (1995), "Corruption and growth," Quarterly Journal of Economics 110, No. 3, August, 681-712.

Paldam, Martin (2000), "Social Capital: One or Many? Definition and Measurement," Journal of Economic Surveys 14, No. 5, December, 629-653.

Ploeg, Frederick van der, and Anthony J. Venables (2012), "Natural Resource Wealth: The Challenge of Managing a Windfall," Annu. Rev. Econ. 4, 315-337.

Ploeg, Frederick van der, and Samuel Wills (2014), "Genuine Saving in East Africa: Guidelines for Exploiting Natural Resource Wealth" (manuscript).

Rodrik, Dani (2004), "Industrial Policy for the Twenty-First Century," CEPR Discussion Paper No. 4767, November.

Ross, Michael (2001), “Does Oil Hinder Democracy?,” World Politics 53, April, 325-361.

Sachs, Jeffrey D., and Andrew M. Warner (1995, revised 1997, 1999), "Natural resource abundance and economic growth," NBER Working Paper 5398, Cambridge, Massachusetts.

Sala-i-Martin, Xavier, and Arvind Subramanian (2013), "Addressing the Natural Resource Curse: An Illustration from Nigeria," Journal of African Economies 22, No. 4, 570-615.

Spence, Michael, et al. (2008), The Growth Report: Strategies for Sustained Growth and Inclusive Development, Commission on Growth and Development, The World Bank, Washington, D.C.

Tignor, Robert L. (2006), W. Arthur Lewis and the Birth of Development Economics, Princeton University Press, Princeton and Oxford.

Wenar, Leif (2008), “Property Rights and the Resource Curse," Philosophy and Public Affairs 36, No. 1, Winter, 1-32.

World Bank (2006), Where Is the Wealth of Nations? Measuring Capital for the 21st Century, Washington, D.C.

Young, Alwyn (2012), “The African Growth Miracle,” Journal of Political Economy 120, No. 4, 696-739. 